\title{
Preparation of a disulfide-linked precipitative soluble support for solution-phase synthesis of trimeric oligodeoxyribo- nucleotide 3'-(2-chlorophenylphosphate) building blocks
}

\author{
Amit M. Jabgunde ${ }^{* 1,2}$, Alejandro Gimenez Molina ${ }^{1}$, Pasi Virta ${ }^{1}$ and Harri Lönnberg ${ }^{1}$
}

\author{
Full Research Paper \\ Address: \\ ${ }^{1}$ Department of Chemistry, University of Turku, FIN-20014 Turku, \\ Finland and ${ }^{2}$ current address: Rega Institute for Medical Research, \\ Minderbroedersstraat 10, KU Leuven, 3000- Leuven, Belgium \\ Email: \\ Amit M. Jabgunde* - amit.jabgunde@gmail.com \\ * Corresponding author \\ Keywords: \\ disulfide linker; oligodeoxyribonucleotides; phosphotriester chemistry; \\ precipitation; soluble support
}

Beilstein J. Org. Chem. 2015, 11, 1553-1560. doi:10.3762/bjoc.11.171

Received: 29 May 2015

Accepted: 19 August 2015

Published: 07 September 2015

Associate Editor: S. Flitsch

(C) 2015 Jabgunde et al; licensee Beilstein-Institut. License and terms: see end of document.

\begin{abstract}
The preparation of a disulfide-tethered precipitative soluble support and its use for solution-phase synthesis of trimeric oligodeoxyribonucleotide 3 '-(2-chlorophenylphosphate) building blocks is described. To obtain the building blocks, $N$-acyl protected $2^{\prime}$-deoxy-5'-O-(4,4'-dimethoxytrityl)ribonucleosides were phosphorylated with bis(benzotriazol-1-yl) 2-chlorophenyl phosphate. The "outdated" phosphotriester strategy, based on coupling of $\mathrm{P}^{\mathrm{V}}$ building blocks in conjunction with quantitative precipitation of the oligodeoxyribonucleotide with $\mathrm{MeOH}$ is applied. Subsequent release of the resulting phosphate and base-protected oligodeoxyribonucleotide trimer 3'- $\mathrm{pTpdC}^{\mathrm{Bz}} \mathrm{pdG}^{\mathrm{ibu}}-5$ ' as its 3'-(2-chlorophenyl phosphate) was achieved by reductive cleavage of the disulfide bond.
\end{abstract}

\section{Introduction}

Synthetic nucleic acids have been used to regulate gene expression through different mechanisms of action, such as antisense oligonucleotides [1,2], ribozymes [3], interfering RNAs (siRNA) $[4,5]$ and immunostimulatory $\mathrm{CpG}[6]$ based therapeutics. At the same time, the interest in detailed understanding of the factors that govern the interaction of nucleic acids with small molecular entities and other biopolymers has increased. In particular, for NMR spectroscopic studies of such interactions, oligonucleotides are often required in quantities that are inconvenient to prepare by laboratory scale solid-phase synthesis. We have previously reported that short oligonucleotides may be conveniently prepared in hundreds of milligrams scale on a soluble tetrakis-O-[4-(1,2,3-triazol-1-yl)methylphenyl]pentaerythritol support that precipitates quantitatively from $\mathrm{MeOH}$ [7-10]. For example, the "outdated" phosphotriester strategy [11-14], exploiting 3'-(2-chlorophenyl phosphate) building blocks works well on this support [8]. No oxidation step is needed and the coupling cycle, hence, contains only two steps: 5 '-deprotection and coupling. To prepare long sequences, it may, however, be necessary to apply convergent solution-phase 
coupling of oligomeric 3 '-(2-chlorophenyl phosphate) building blocks [15]. For the preparation of such building blocks, a 2-hydroxyethyldisulfanyl functionalized support may in principle be used [16-21]. After completion of the chain assembly on the hydroxy function, the disulfide linkage may be reductively cleaved and the phosphate bound 2-mercaptoethyl group is removed. Accordingly, the oligomer expectedly is released in a fully protected form. We now report on the synthesis of such a soluble support, $\mathbf{3}$, and show that it allows efficient coupling by the 1-hydroxybenzotriazole promoted phosphotriester coupling $[11,22,23]$ and efficient purification of the support bound product by precipitation from $\mathrm{MeOH}$ after each deprotection and coupling step.

\section{Results and Discussion}

The synthesis of the disulfide tethered tetrakis-O-(\{4-[(2hydroxyethyldisulfanyl)methyl]-1H-1,2,3-triazol-1-ylmethylphenyl pentaerythritol support (3) is outlined in Scheme 1 . Commercially available $S$-propargyl thioacetate was first conjugated to the tetrakis- $O$-[4-(azidomethylphenyl)pentaerythritol support (1) [7] by $\mathrm{Cu}(\mathrm{I})$ catalyzed 1,3-dipolar cycloaddition [24,25], yielding tetrakis-O-(\{4-[4-[(acetylthio-
methyl)]-1H-1,2,3-triazol-1-ylmethyl]phenyl \} pentaerythritol (2) as a thick oil. Careful aminolysis of the thioacetates with butylamine in degassed methanol under inert atmosphere followed by immediate reaction of the exposed mercapto groups with 2-(pyridine-2-yldisulfanyl)ethanol gave the desired tetrapodal soluble support $\mathbf{3}$.

Previously [11] described phosphorylation with bis(benzotriazol-1-yl) 2-chlorophenyl phosphate in 1,4-dioxane was applied to convert commercial thymidine, $N^{4}$-benzoyl-2'-deoxycytidine and $N^{2}$-isobutyryl-2'-deoxyguanosine into their 3'-(benzotriazol-1-yl 2-chlorophenyl phosphates) (4-6; Scheme 2). The stock solution of the latter reagent $\left(0.2 \mathrm{~mol} \mathrm{~L}^{-1}\right)$ was prepared as described in our previous report [8].

A trimeric oligodeoxyribonucleotide containing three different 2 '-deoxyribonucleosides was assembled on support $\mathbf{3}$ as depicted in Scheme 3. The couplings were carried out essentially as described previously [8]. Accordingly, the dried support was treated under nitrogen with the thymidine derived building block 4 ( 2 equiv per support-bound $\mathrm{OH}$ ), in dioxane in the presence of 1-methylimidazole. The coupling was

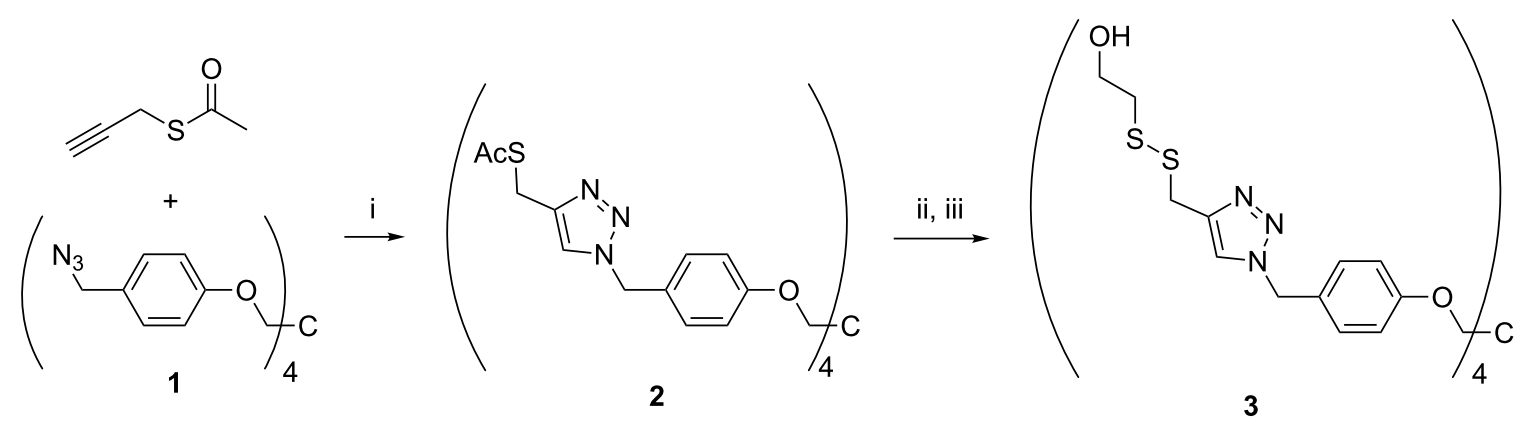

Scheme 1: Synthesis of soluble support. Reagents and conditions: (i) Cul, sodium ascorbate, DMAC, $50{ }^{\circ} \mathrm{C}, 12 \mathrm{~h}$; (ii) butylamine, MeOH, room temperature, $12 \mathrm{~h}$; (iii) 2-(pyridine-2-yldisulfanyl)ethanol, MeCN/DCM/MeOH, $0.5 \mathrm{~h}$.

Scheme 2: Activation of nucleosides. Reagents and conditions: (i) pyridine, dry dioxane, room temperature, $3 \mathrm{~h}$. 

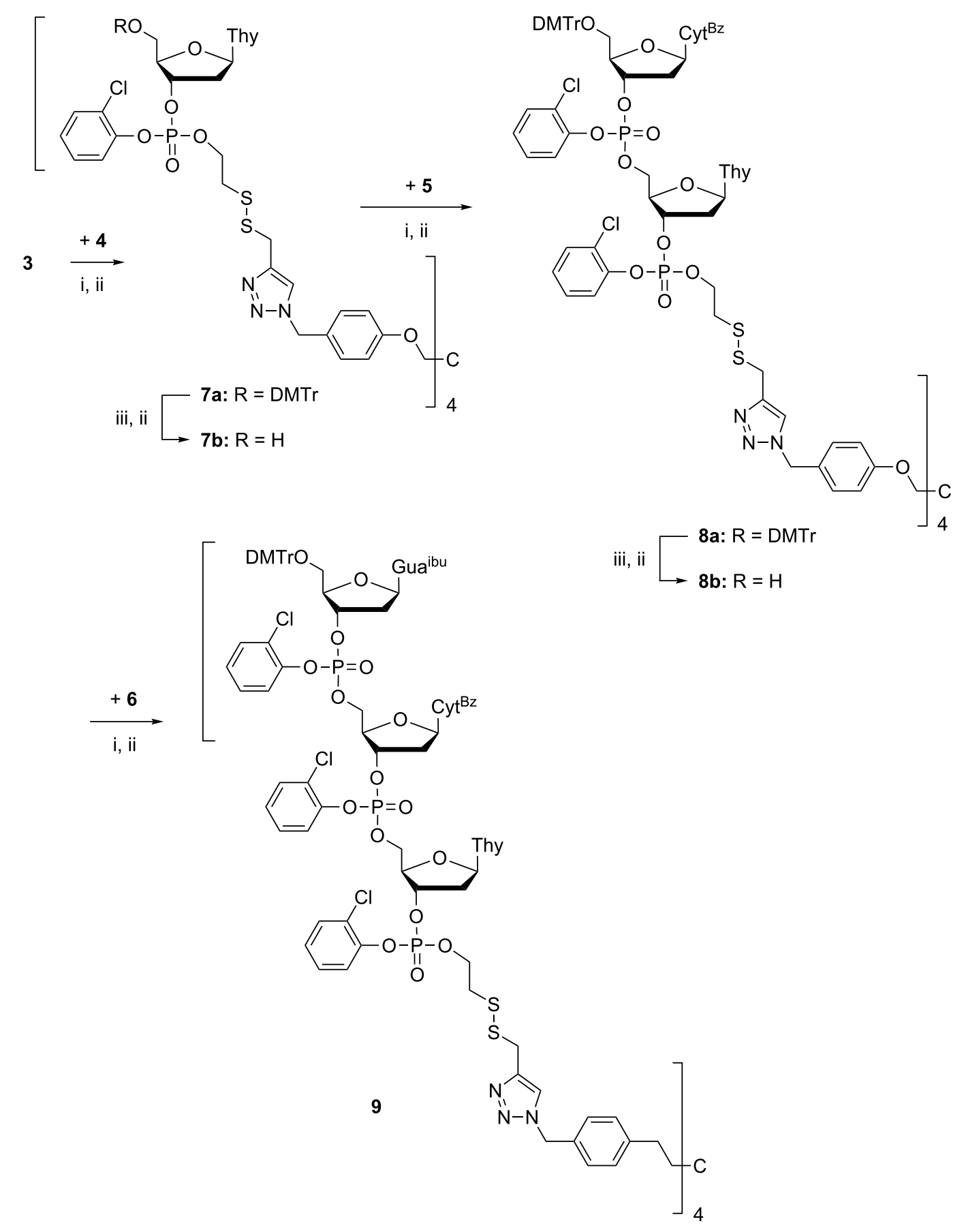

Scheme 3: Synthesis of oligonucleotides. Reagents and conditions: (i) 4-6, 1-methylimidazole, dioxane, under $\mathrm{N}_{2}$; (ii) precipitation with MeOH; (iii) 1. $\mathrm{HCl}$ in $\mathrm{MeOH} / \mathrm{DCM}(1: 1)$; 2. pyridine, solvent evaporation.

completed in $12 \mathrm{~h}$, and the excess of $\mathbf{4}$ and the coupling reagents were removed by precipitating the support with $\mathrm{MeOH}$ to obtain 7a. According to TLC analysis, the precipitation was quantitative. Detritylation of $7 \mathbf{a}$ with $\mathrm{HCl}$ in a $1: 1$ mixture of $\mathrm{MeOH}$ and DCM, followed by neutralization with pyridine, concentration to oil and precipitation from $\mathrm{MeOH}$, afforded $\mathbf{7 b}$.
HPLC-analysis verified the completeness of precipitation (Figure 1).

Building blocks 5 and $\mathbf{6}$ were then coupled similarly to obtain 9 (Scheme 3). The identity and homogeneity of the product were verified by ESIMS and HPLC after each coupling and 5 '-depro- 


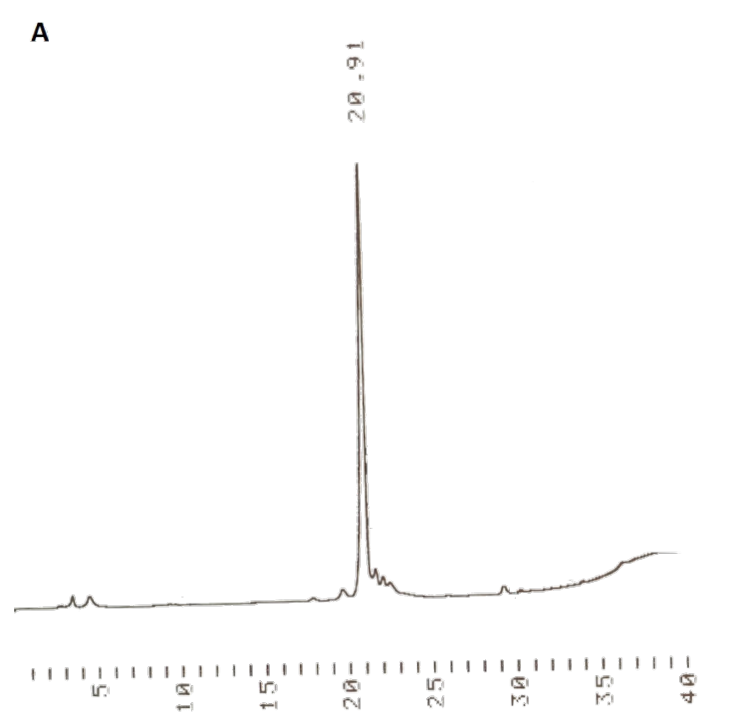

B

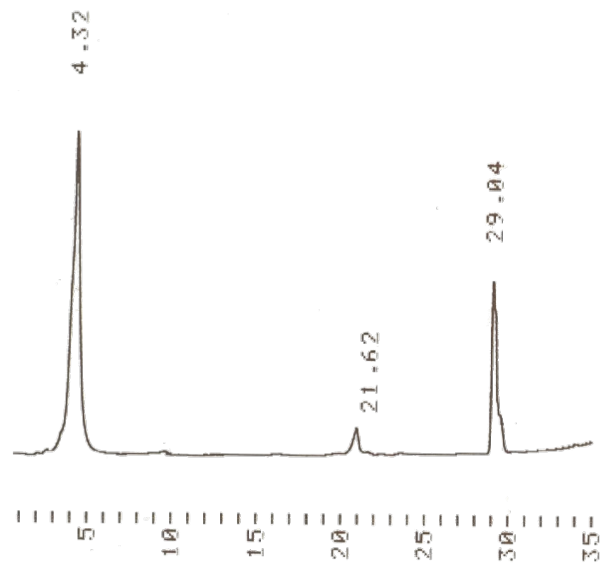

Figure 1: (A) HPLC traces for the precipitated support bearing phosphate-protected 3'-T-5' monomer having the 5'-hydroxy group detritylated (7b), and (B) HPLC traces of the filtrate after precipitation. For the chromatographic conditions, see gradient $A$ in the Experimental section.

tection step. The MS data are given in Table 1. Figure 2 and Figure 3 show as an illustrative example the HPLC traces for $\mathbf{8 a}, \mathbf{8 b}$ and 9 precipitated from $\mathrm{MeOH}$ and the filtrate of precipitation. As seen, the precipitation is virtually quantitative.

The trimer prepared was then released from the support by cleaving the disulfide linkage by TCEP reduction. The phosphate bound 2-mercaptoethyl group was removed spontaneously giving the oligonucleotide trimer expectedly as a in fully
Table 1: ESIMS characterization of the support-bound nucleotides indicated in Scheme 3.

\section{Compound Calculated mass Observed mass}

$\begin{array}{lll}\mathbf{7 a} & 2060.0[(\mathrm{M}-2 \mathrm{H}) / 2]^{2-} & 2059.9[(\mathrm{M}-2 \mathrm{H}) / 2]^{2-} \\ \mathbf{7 b} & 1455.3[(\mathrm{M}-2 \mathrm{H}) / 2]^{2-} & 1455.2[(\mathrm{M}-2 \mathrm{H}) / 2]^{2-} \\ \mathbf{8 a} & 3067.7[(\mathrm{M}-2 \mathrm{H}) / 2]^{2-} & 3067.7[(\mathrm{M}-2 \mathrm{H}) / 2]^{2-} \\ \mathbf{8 b} & 2462.9[(\mathrm{M}-2 \mathrm{H}) / 2]^{2-} & 2462.7[(\mathrm{M}-2 \mathrm{H}) / 2]^{2-} \\ \mathbf{9} & 2724.6[(\mathrm{M}-3 \mathrm{H}) / 3]^{3-} & 2724.5[(\mathrm{M}-3 \mathrm{H}) / 3]^{3-}\end{array}$

A

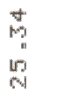

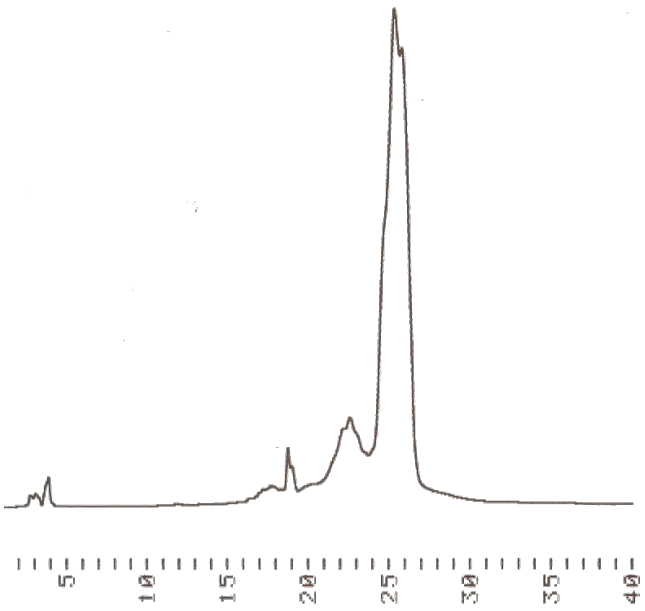

B

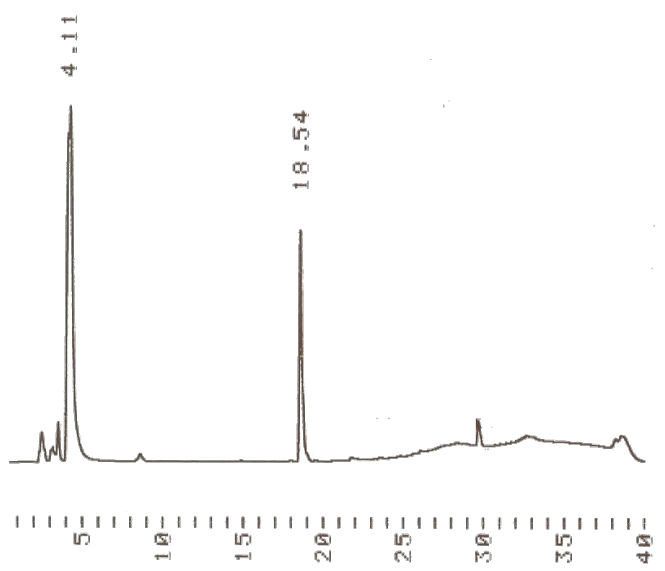

Figure 2: (A) HPLC traces for the precipitated support bearing phosphate-protected 3'-pTpdC ${ }^{B z}-5^{\prime}-O-D M T r(8 a)$ and (B) HPLC traces of the filtrate after precipitation. For the chromatographic conditions, see gradient $\mathrm{B}$ in the Experimental section. 


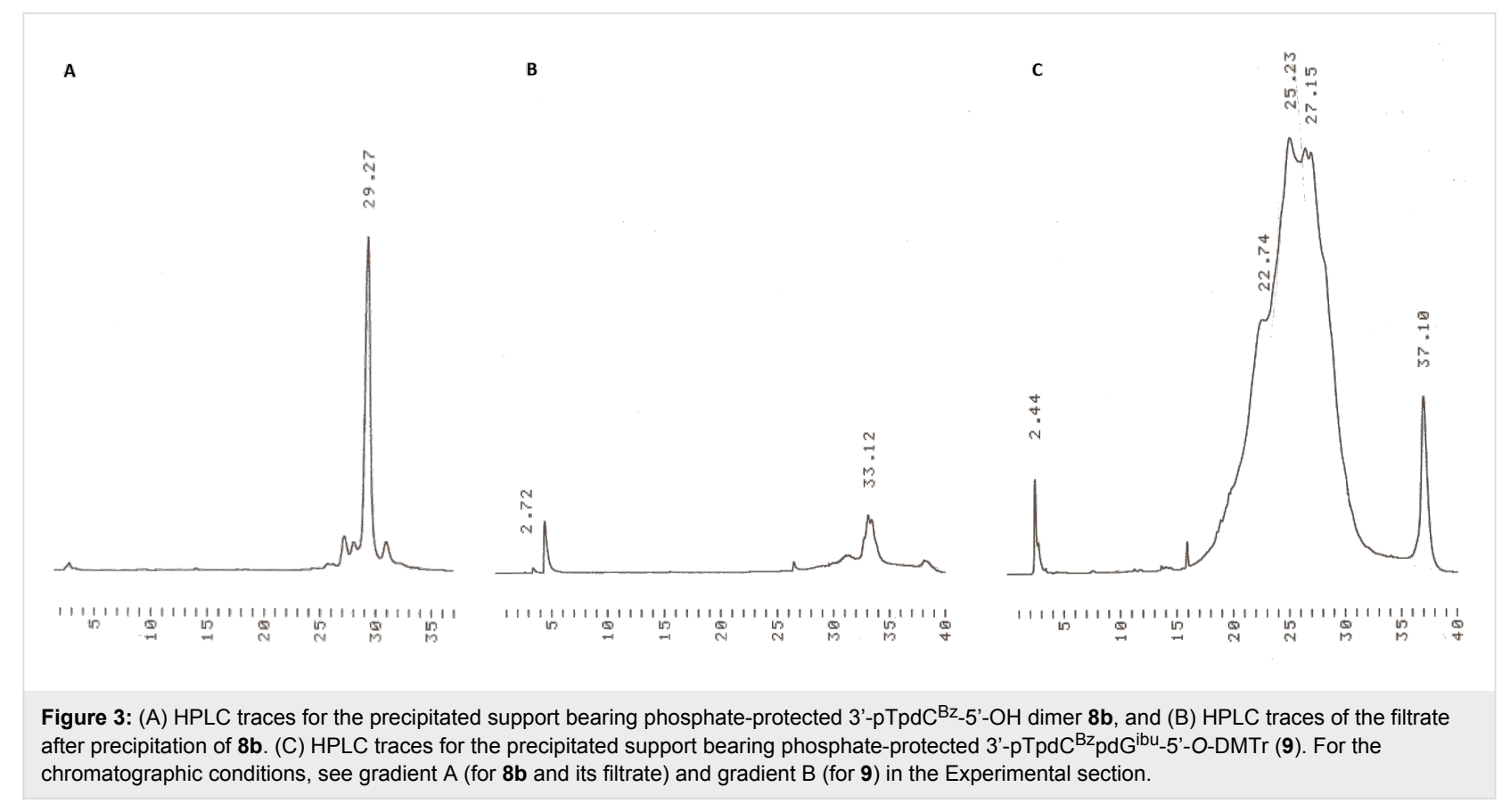

protected 3'-(2-chlorophenyl phosphate). While the phosphate and base moiety protections remained intact, the $5^{\prime}-O-\left(4,4^{\prime}-\right.$ dimethoxytrityl) group was unfortunately lost (Scheme 4). It has been previously shown [26] that the disulfide linkage may be cleaved by reduction with dithiotreitol or TCEP at $\mathrm{pH}$ buffered to 7.6 without detritylation taking place. Elongated treatment with TCEP appeared, however, to be too harsh. Evidently, the 5'-terminal nucleoside should be inserted as a more acid tolerant $5^{\prime}-O$-(4-methoxytrityl) protected building

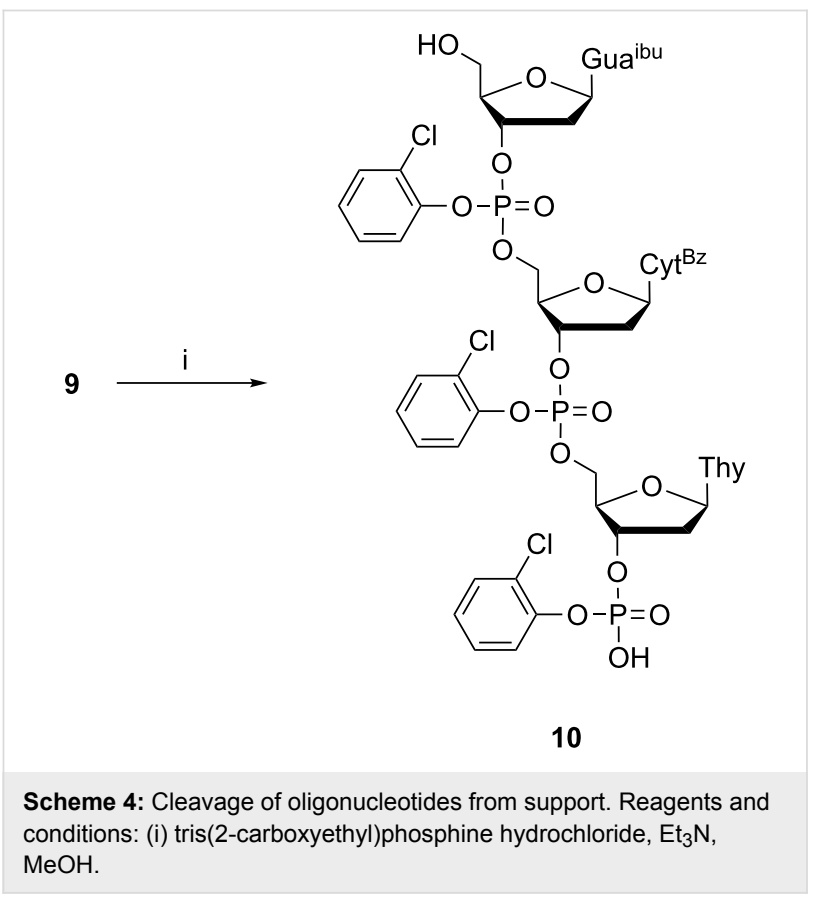

block. The concentrated reaction mixture was washed with $\mathrm{MeCN}$ and collected washings having crude trimer were dried and purified by semi-preparative HPLC to afford pure trimer oligodeoxyribonucleotide (10).

\section{Conclusion}

Tetrakis-O-(\{4-[4-[(2-hydroxyethyldisulfanylmethyl)]-1 $H$ 1,2,3-triazol-1-ylmethyl]phenyl \} pentaerythritol (3) has been synthesized and used as a tetrapodal soluble support for the synthesis of a fully protected trimeric oligodeoxyribonucleotide as a 3 '-(2-chlorophenyl phosphate) by the 1-hydroxybenzotriazole promoted phosphotriester chemistry. The support enabled efficient purification of the support-bound intermediates and product by virtually quantitative precipitation from $\mathrm{MeOH}$ after each coupling and 5 - $O$-deprotection. However, on assembling the trimeric 3 '-(2-chlorophenyl phosphate) building blocks, the 5 '-terminal nucleoside should be introduced in a 5 '-O-(4methoxytrityl) protected form to prevent detritylation during the reductive cleavage of the trimer from the support.

\section{Experimental}

General: NMR spectra were recorded on a Bruker Avance spectrometer $(500$ or $400 \mathrm{MHz})$ at $25^{\circ} \mathrm{C}$. Chemical shifts are given in ppm and referenced relative to the residual solvent signals. RP HPLC conditions: (A) gradient elution from $25 \% \mathrm{MeCN}$ in $0.1 \mathrm{~mol} \mathrm{~L}^{-1} \mathrm{Et}_{3} \mathrm{NHOAc}$ to $70 \% \mathrm{MeCN}$ in $0.1 \mathrm{~mol} \mathrm{~L}^{-1}$ $\mathrm{Et}_{3} \mathrm{NHOAc}$ in $25 \mathrm{~min}$, then continued with $70 \% \mathrm{MeCN}$ in $0.1 \mathrm{~mol} \mathrm{~L}^{-1} \mathrm{Et}_{3} \mathrm{NHOAc}$ to $100 \% \mathrm{MeCN}$ in $35 \mathrm{~min}$; (B) gradient elution from $25 \% \mathrm{MeCN}$ in $0.1 \mathrm{~mol} \mathrm{~L}^{-1} \mathrm{Et}_{3} \mathrm{NHOAc}$ to $100 \%$ $\mathrm{MeCN}$ in $25 \mathrm{~min}$, then continued with $\mathrm{MeCN}$; An analytical 
C-18 RP column $\left(250 \times 4.6 \mathrm{~mm}, 5 \mu \mathrm{m}\right.$; flow rate $1.0 \mathrm{~mL} \mathrm{~min}{ }^{-1}$; $\lambda=260 \mathrm{~nm}$ ) was used. Reactions were monitored by TLC (Merck, silica gel $60 \mathrm{~F}_{254}$ ), using short wavelength UV or charring with $10 \%$ aq $\mathrm{H}_{2} \mathrm{SO}_{4}$ for detection (system $\mathrm{A}: 5 \% \mathrm{MeOH}$ in $\mathrm{CH}_{2} \mathrm{Cl}_{2}$; system B: $10 \% \mathrm{MeOH}$ in $\mathrm{CH}_{2} \mathrm{Cl}_{2}$ ). Mass spectra were recorded with a Bruker Daltonics MicrOTOFQ spectrometer using ESI mode.

Tetrakis-O-(4-azidomethylphenyl)pentaerythritol (1) was prepared as described previously [7].

Tetrakis- $O$-\{4-[4-(acetylthiomethyl)-1H-1,2,3-triazol-1ylmethyl]phenyl\}pentaerythritol (2): $S$-Propargyl thioacetate $(1.73 \mathrm{~mL}, 15.0 \mathrm{mmol})$ was added to the solution of compound $\mathbf{1}$ $(1.00 \mathrm{~g}, 1.51 \mathrm{mmol})$, sodium ascorbate $(30 \mathrm{mg}, 0.15 \mathrm{mmol})$ and $\mathrm{CuI}(115 \mathrm{mg}, 0.605 \mathrm{mmol})$ in dry DMAc $(5.0 \mathrm{~mL})$ in a Pyrex tube. The tube was degassed via three freeze-pump-thaw cycles, and the mixture was stirred at $50{ }^{\circ} \mathrm{C}$ for $12 \mathrm{~h}$. Water $(10 \mathrm{~mL})$ was added to the reaction mixture and extracted with ethyl acetate $(20 \mathrm{~mL} \times 3)$. The combined organic layer was washed with saturated $\mathrm{NaHCO}_{3}$, dried with $\mathrm{Na}_{2} \mathrm{SO}_{4}$, and the solvents were evaporated to dryness. The residue was purified by silica gel chromatography $\left(\mathrm{CH}_{2} \mathrm{Cl}_{2} / \mathrm{MeOH}, 97: 3 \mathrm{v} / \mathrm{v}\right)$ to give $2(1.2 \mathrm{~g}, 70 \%)$ as a white foam. ${ }^{1} \mathrm{H} \mathrm{NMR}\left(400 \mathrm{MHz}, \mathrm{CDCl}_{3}\right) \delta$ 7.35 (s, 4H, H5 of triazole), 7.18 (d, $J=8.6 \mathrm{~Hz}, 8 \mathrm{H}, \mathrm{H} 2 \& \mathrm{H} 6$ of $\mathrm{Ph}), 6.89(\mathrm{~d}, J=8.6 \mathrm{~Hz}, 8 \mathrm{H}, \mathrm{H} 3 \& \mathrm{H} 5$ of $\mathrm{Ph}), 5.38(\mathrm{~s}, 8 \mathrm{H}$, $\left.\mathrm{N}-\mathrm{CH}_{2}-\mathrm{Ph}\right), 4.32\left(\mathrm{~s}, 8 \mathrm{H}, \mathrm{AcS}-\mathrm{CH}_{2}-\right), 4.13\left(\mathrm{~s}, 8 \mathrm{H}, \mathrm{CH}_{2}-\right.$ pentaerythritol), 2.31 (s, 12H, -SAc); ${ }^{13} \mathrm{C}$ NMR $(125 \mathrm{MHz}$, $\left.\mathrm{CDCl}_{3}\right) \delta 195.2,158.9,144.6,129.7,127.2,122.1,115.1,66.4$, 53.6, 44.7, 30.4, $23.9 \mathrm{ppm}$; ESIMS $\mathrm{m} / z:[\mathrm{M}+\mathrm{H}]^{+}$calcd for $\mathrm{C}_{53} \mathrm{H}_{57} \mathrm{~N}_{12} \mathrm{O}_{8} \mathrm{~S}_{4}, 1117.33$, found, 1117.36; m/z: $[\mathrm{M}+\mathrm{Na}]^{+}$ calcd for $\mathrm{C}_{53} \mathrm{H}_{56} \mathrm{~N}_{12} \mathrm{NaO}_{8} \mathrm{~S}_{4}, 1139.31$; found, 1139.32 .

Tetrakis-O-\{4-[4-(2-hydroxyethyldisulfanylmethyl)- $1 \mathrm{H}$ 1,2,3-triazol-1-ylmethyl]phenyl\} pentaerythritol (3). Degassed butylamine in $\mathrm{MeOH}\left(0.21 \mathrm{~mL}, 1.0 \mathrm{~mol} \mathrm{~L}^{-1}\right.$, $2.15 \mathrm{mmol})$ was added to the stirred solution of compound 2 (600 mg, $0.537 \mathrm{mmol}$ ) in degassed $\mathrm{MeOH}$. The mixture was stirred under $\mathrm{N}_{2}$ for $12 \mathrm{~h}$. Degassed MeCN/DCM (5 mL, 1:1 $\mathrm{v} / \mathrm{v}$ ) was added and the mixture was neutralized with dry acidic ion exchange resin and filtered off. The solvent was removed by evaporation and the crude product was used in the next reaction without purification. 2-(Pyridine-2-yldisulfanyl)ethanol (581 mg, $3.11 \mathrm{mmol}$ ) was added to the crude compound in degassed MeCN/DCM/MeOH (4 mL, 2:1:1 v/v/v) under $\mathrm{N}_{2}$. The mixture was stirred for $30 \mathrm{~min}$ and the progress was monitored by TLC. Solvents were removed by evaporation and the product was purified by silica gel chromatography (DCM/ $\mathrm{MeOH}, 95: 5 \mathrm{v} / \mathrm{v})$ to give $3(120 \mathrm{mg}, 19 \%)$ as a thick oil. ${ }^{1} \mathrm{H}$ NMR (500 MHz, $\mathrm{CDCl}_{3}$ ) $\delta 7.40$ (s, 4H, H5 of triazole), 7.18 (d, $J=8.6 \mathrm{~Hz}, 8 \mathrm{H}, \mathrm{H} 2 \& \mathrm{H} 6$ of $\mathrm{Ph}$ ), 6.88 (d, $J=8.6 \mathrm{~Hz}, 8 \mathrm{H}$,
$\mathrm{H} 3 \& \mathrm{H} 5$ of $\mathrm{Ph}$ ), 5.42 (s, 8H, N-CH$\left.H_{2} \mathrm{Ph}\right), 4.30$ (s, 8H, S-CH $2^{-}$ triazole), 3.97 (s, $8 \mathrm{H}, \mathrm{CH}_{2}$-pentaerythritol), 3.79 (t, $J=5.5 \mathrm{~Hz}$, $8 \mathrm{H}, \mathrm{CH}_{2} \mathrm{OH}$ ), 2.73 (br t, 8H, S- $\mathrm{CH}_{2} \mathrm{CH}_{2}$ ) ppm; ${ }^{13} \mathrm{C}$ NMR (100 $\left.\mathrm{MHz}, \mathrm{CDCl}_{3}\right) \delta 158.9,144.2,129.6,127.2,121.9,115.2,66.4$, 59.9, 53.7, 44.8, 42.5, 32.8 ppm; ESIMS $m / z:[\mathrm{M}+\mathrm{H}]^{+}$calcd for $\mathrm{C}_{53} \mathrm{H}_{65} \mathrm{~N}_{12} \mathrm{O}_{8} \mathrm{~S}_{8}, 1253.28$; found, $1253.27 ; \mathrm{m} / \mathrm{z}$ : $[\mathrm{M}+\mathrm{Na}]^{+}$ calcd for $\mathrm{C}_{53} \mathrm{H}_{64} \mathrm{~N}_{12} \mathrm{NaO}_{8} \mathrm{~S}_{8}, 1275.26$; found, 1275.26.

Bis(benzotriazol-1-yl) 2-chlorophenyl phosphate: The couplings were carried out essentially as described previously [8]. A solution of 2-chlorophenyl phosphorodichloridate (7.6 mmol, $1.88 \mathrm{~g})$ in anhydrous dioxane $(5.75 \mathrm{~mL})$ was added in one portion to a suspension of 1-hydroxybenzotriazole (15.2 mmol, $2.06 \mathrm{~g}$; dried in vacuo over $\mathrm{P}_{2} \mathrm{O}_{5}$ at $55^{\circ} \mathrm{C}$ for $3 \mathrm{~d}$ ) and pyridine $(15 \mathrm{mmol}, 1.2 \mathrm{~mL})$ in anhydrous dioxane $(30 \mathrm{~mL})$. The reaction mixture was stirred for $2 \mathrm{~h}$, and the precipitate was filtered off under anhydrous conditions to give a stock solution of bis(benzotriazol-1-yl) 2-chlorophenyl phosphate $\left(0.2 \mathrm{~mol} \mathrm{~L}^{-1}\right)$ as a clear colorless liquid. The solution $\left(\rho=1.057 \mathrm{~g} \mathrm{~L}^{-1}\right.$ ) could be stored for several weeks at $-20{ }^{\circ} \mathrm{C}$.

General procedure for the coupling of 1-hydroxybenzotriazole-activated phosphotriester building blocks: The coupling cycle was analogous to that described previously [8]. 5'-O(4,4'-Dimethoxytrityl)thymidine $(0.30 \mathrm{~g}, 0.54 \mathrm{mmol})$ was dried by co-evaporation with anhydrous pyridine $(3 \times 5 \mathrm{~mL})$ and concentrated to a small volume followed by the addition of the stock solution of bis(benzotriazol-1-yl) 2-chlorophenyl phosphate in dioxane $\left(0.54 \mathrm{mmol}, 0.2 \mathrm{~mol} \mathrm{~L}^{-1}, 2.72 \mathrm{~mL}\right)$, giving 5'-O-(4,4'-dimethoxytrityl)thymidine 3'-(benzotrizol-1-yl 2-chlorophenyl phosphate) 4 in dioxane. The formation of a product with zero mobility on TLC (system B) indicated that the reaction was complete. In a separate vessel, support 3 ( $0.068 \mathrm{mmol}, 0.086 \mathrm{~g})$ was dried by co-evaporation with anhydrous pyridine $(3 \times 5 \mathrm{~mL})$, and then 4 in dioxane and 1-methylimidazole ( $2 \mathrm{mmol}, 0.218 \mathrm{~mL}$ ) were added under nitrogen. The reaction mixture was stirred for $2 \mathrm{~h}$ to obtain the tetravalent nucleoside cluster $\mathbf{7 a}$, transferred to a stoppered $50 \mathrm{~mL}$ plastic tube, and $\mathrm{MeOH}(46 \mathrm{~mL})$ was added. The precipitate formed was kept at $-20{ }^{\circ} \mathrm{C}$ overnight, isolated by centrifugation, and dried to give $7 \mathbf{a}(0.20 \mathrm{~g}, 70 \%)$ as a white solid. The precipitate and supernatant were analyzed by HPLC to verify the completeness of precipitation and the identity of the precipitate was verified by ESIMS (Table 1).

General procedure for detritylation: The detritylation cycle was analogous to that described previously [8].Tetravalent support-bound thymidine monomer $7 \mathbf{a}(0.048 \mathrm{mmol}, 0.20 \mathrm{~g})$ was dissolved in a mixture of DCM and $\mathrm{MeOH}(1: 1 \mathrm{v} / \mathrm{v}$, $25 \mathrm{~mL})$, and $\mathrm{HCl}$ in $\mathrm{MeOH}\left(0.115 \mathrm{~mL}\right.$ of $1.25 \mathrm{~mol} \mathrm{~L}^{-1}$ solution) was added portion wise. The reaction was monitored by TLC 
(system A). Once completed, the reaction mixture was neutralized with pyridine $(1 \mathrm{~mL})$, and the liquid was concentrated. The resulting oil was dissolved in $\mathrm{DCM} / \mathrm{MeOH}(1: 1,3 \mathrm{~mL})$, and $\mathrm{MeOH}$ was added $(40 \mathrm{~mL})$. The precipitate formed was kept at $-20{ }^{\circ} \mathrm{C}$ overnight, collected by centrifugation and dried to give the product $7 \mathbf{b}(0.120 \mathrm{~g}, 85 \%)$ as a white solid. The precipitate and supernatant were analyzed by HPLC (Figure 1) and the precipitate by ESIMS (Table 1).

Cleavage from tetravalent soluble support: To the solution of support-bound trimer $9(0.0061 \mathrm{mmol}, 0.045 \mathrm{~g})$ in $\mathrm{MeOH}$ $(1 \mathrm{~mL})$, triethylamine $(1.44 \mathrm{mmol}, 0.2 \mathrm{~mL})$ and tris $(2-$ carboxyethyl)phosphine ( $0.027 \mathrm{mmol}, 0.008 \mathrm{~g})$, stirred for $3 \mathrm{~h}$, and then volatiles were removed under reduced pressure. The residue was stirred with $\mathrm{CH}_{3} \mathrm{CN}(3 \mathrm{~mL})$ for $15 \mathrm{~min}$ and the precipitated support was removed by filtration, the filtrate was concentrated and dried in vacuo to give a yellow oil. The oily residue was purified by semi-preparative HPLC to afford the phosphate protected trimer oligodeoxyribonucleotide $\mathbf{1 0}$ $(20 \mathrm{mg}, 57 \%)$. ESIMS $\mathrm{m} / \mathrm{z}:[\mathrm{M}+\mathrm{H}]^{+}$calcd for $\mathrm{C}_{58} \mathrm{H}_{59} \mathrm{~N}_{10} \mathrm{O}_{22} \mathrm{P}_{3}, 1445.21$; found, 1445.20; $\mathrm{m} / \mathrm{z}:[\mathrm{M}+\mathrm{Na}]^{+}$ calcd for $\mathrm{C}_{58} \mathrm{H}_{58} \mathrm{~N}_{10} \mathrm{NaO}_{22} \mathrm{P}_{3}, 1467.19$; found, 1467.18 .

\section{Supporting Information}

\section{Supporting Information File 1}

${ }^{1} \mathrm{H}$ NMR, ${ }^{13} \mathrm{C}$ NMR and DEPT spectra for $\mathbf{2}$, and $\mathbf{3}$,

${ }^{31} \mathrm{P}$ NMR spectra of $\mathbf{1 0}$, mass spectra for $\mathbf{2}, \mathbf{3}, \mathbf{7 a}-\mathbf{1 0}$.

[http://www.beilstein-journals.org/bjoc/content/

supplementary/1860-5397-11-171-S1.pdf]

\section{Acknowledgements}

Financial support from the FP7 Marie Curie Actions is gratefully acknowledged. AJ is thankful to FP7 Marie Curie Actions for ITN experienced researcher fellowship and Erasmus Mundus EXPERTS-II, for postdoctoral fellowship.

\section{References}

1. Watts, J. K.; Corey, D. R. J. Pathol. 2012, 226, 365-379. doi:10.1002/path.2993

2. Kole, R.; Krainer, A. R.; Altman, S. Nat. Rev. Drug Discovery 2012, 11, 125-140. doi:10.1038/nrd3625

3. Usman, N.; Blatt, L. M. J. Clin. Invest. 2000, 106, 1197-1202. doi:10.1172/JCl11631

4. Li, T.; Wu, M.; Zhu, Y. Y.; Chen, J.; Chen, L. Nucleic Acid Ther. 2014, 24, 302-312. doi:10.1089/nat.2014.0480

5. Burnett, J. C.; Rossi, J. J. Chem. Biol. 2012, 19, 60-71. doi:10.1016/j.chembiol.2011.12.008

6. Krieg, A. M. Nucleic Acid Ther. 2012, 22, 77-89.

7. Kungurtsev, V.; Laakkonen, J.; Gimenez Molina, A.; Virta, P. Eur. J. Org. Chem. 2013, 6687-6693. doi:10.1002/ejoc.201300864
8. Kungurtsev, V.; Virta, P.; Lönnberg, H. Eur. J. Org. Chem. 2013, 7886-7890. doi:10.1002/ejoc.201301352

9. Gimenez Molina, A.; Jabgunde, A. M.; Virta, P.; Lönnberg, H. Beilstein J. Org. Chem. 2014, 10, 2279-2285. doi:10.3762/bjoc.10.237

10. Gimenez Molina, A.; Jabgunde, A. M.; Virta, P.; Lönnberg, H. Curr. Org. Synth. 2015, 12, 202-207. doi:10.2174/1570179411666141120215703

11. de Vroom, E.; Fidder, A.; Marugg, J. E.; van der Marel, G. A.; van Boom, J. H. Nucleic Acids Res. 1986, 14, 5885-5900. doi:10.1093/nar/14.14.5885

12. Reese, C. B.; Zhang, P.-Z. J. Chem. Soc., Perkin Trans. 11993 , 2291-2301. doi:10.1039/p19930002291

13. Bonora, G. M.; Scremin, C. L.; Colonna, F. P.; Garbesi, A. Nucleic Acids Res. 1990, 18, 3155-3159. doi:10.1093/nar/18.11.3155 14. Colonna, F. P.; Scremin, C. L.; Bonora, G. M. Tetrahedron Lett. 1991, 32, 3251-3254. doi:10.1016/S0040-4039(00)79736-X

15. Jones, S. S.; Rayner, B.; Reese, C. B.; Ubasawa, A.; Ubasawa, M. Tetrahedron 1980, 36, 3075-3085. doi:10.1016/0040-4020(80)88035-5

16. Zuckerman, R.; Corey, D.; Schultz, P. Nucleic Acids Res. 1987, 15, 5305-5321. doi:10.1093/nar/15.13.5305

17. Gupta, K. C.; Sharma, P.; Sathyanarayana, S.; Kumar, P. Tetrahedron Lett. 1990, 31, 2471-2474. doi:10.1016/S0040-4039(00)97392-1

18. Asseline, U.; Nguyen, T. T. Tetrahedron Lett. 1990, 31, 81-84. doi:10.1016/S0040-4039(00)94339-9

19. Kumar, P.; Bose, N. K.; Gupta, K. C. Tetrahedron Lett. 1991, 32 , 967-970. doi:10.1016/S0040-4039(00)92132-4

20. Bonfils, B.; Thuong, N. T. Tetrahedron Lett. 1991, 32, 3053-3056. doi:10.1016/0040-4039(91)80686-Z

21. Salo, H.; Guzaev, A.; Lönnberg, H. Bioconjugate Chem. 1998, 9 , 365-371. doi:10.1021/bc970194g

22. van der Marel, G.; van Boeckel, C. A. A.; Wille, G.; van Boom, J. H. Tetrahedron Lett. 1981, 22, 3887-3890. doi:10.1016/S0040-4039(01)91336-X

23. Marugg, J. E.; McLaughlin, L. W.; Piel, N.; Tromp, M.; van der Marel, G. A.; van Boom, J. H. Tetrahedron Lett. 1983, 24 , 3989-3992. doi:10.1016/S0040-4039(00)88244-1

24. Rostovtsev, V. V.; Green, L. G.; Fokin, V. V.; Sharpless, K. B. Angew. Chem., Int. Ed. 2002, 41, 2596-2599. doi:10.1002/1521-3773(20020715)41:14<2596::AID-ANIE2596>3.0.CO ;2-4

25. Tornøe, C. W.; Christensen, C.; Meldal, M. J. Org. Chem. 2002, 67, 3057-3064. doi:10.1021/jo011148j

26. Semenyuk, A.; Földesi, A.; Johansson, T.; Estmer-Nilsson, C.; Blomgren, P.; Brännvall, M.; Kirsebom, L. A.; Kwiatkowski, M. J. Am. Chem. Soc. 2006, 128, 12356-12357. doi:10.1021/ja0636587 


\section{License and Terms}

This is an Open Access article under the terms of the Creative Commons Attribution License

(http://creativecommons.org/licenses/by/2.0), which permits unrestricted use, distribution, and reproduction in any medium, provided the original work is properly cited.

The license is subject to the Beilstein Journal of Organic Chemistry terms and conditions:

(http://www.beilstein-journals.org/bjoc)

The definitive version of this article is the electronic one which can be found at:

$\underline{\text { doi:10.3762/bjoc. } 11.171}$ 